\section{Noticias y comentarios}

\title{
Alicante lidera un proyecto para la difusión del patrimonio cultural universitario
}

El proyecto Patrimonio Cultural Universitario nace ante el vacío que existe respecto al conocimiento del patrimonio cultural tangible e intangible de las universidades españolas, tanto por parte de la comunidad universitaria como del resto de la sociedad. Las universidades, desde sus origenes, han acumulando materiales que se han utilizado en la docencia y que con el paso del tiempo y el incremento de las piezas pasaron a ser colecciones de distinta naturaleza. También han recibido donaciones, depósitos, han generado materiales y los han comprado. Su propia infraestructura es patrimonio cultural: sus edificios, su urbanismo, sus jardines, calles, etc. De la misma manera hay que tener en cuenta el patrimonio académico, es decir, la herencia teórica y filosófica que nace en los claustros universitarios. Pero curiosamente las actividades académicas y extra académicas universitarias se han dirigido al estudio, investigación y promoción del clásico patrimonio histórico olvidando el suyo propio. Los factores que han generado esta situación han sido varios pero fundamentalmente se debe al desconocimiento y al poco valor que se ha dado al patrimonio cultural de las universidades. Como consecuencia de ello muchas universidades no poseen un inventario ni un catálogo razonado de su patrimonio cultural con el consiguiente peligro de desaparición, robo y deterioro de las piezas.

Desde el año 1995 comenzamos a recoger información acerca del patrimonio cultural de las universidades y en aquel momento el desconocimiento sobre el tema era desolador. Hoy en día la situación ha cambiado y en algunos centros se cuenta con un técnico específico de patrimonio cultural, pero falta mucho por hacer. Aún quedan universidades que no poseen un inventario ni una base de datos. Ello nos ha llevado a cuestionar las limitaciones sobre el tratamiento científico del patrimonio cultural y a promover acciones que incluyan su análisis, estudio, conservación y difusión.

El adelanto tecnológico y las nuevas corrientes que conciben al patrimonio cultural en un sentido amplio (bienes tangibles e intangibles) han creado un escenario adecuado para replantear los estudios del patrimonio cultural e incluirlo en las investigaciones así como en las diversas acciones de los órganos universitarios.

Ante esta perspectiva el proyecto Patrimonio Cultural Universitario se propuso los siguientes objetivos:

> Recuperar, proteger y difundir el patrimonio cultural universitario (tangible e intangible)

> Elaborar una base de datos contrastada y con base científica de modo que pueda servir como he- rramienta para los estudios sobre el Patrimonio Cultural Universitario

$>$ Crear un portal con libertad de acceso para todas las universidades

> Alcanzar un modelo homologado de catalogación y sistematización

$>$ Constituir un foro académico para debatir la problemática y alternativas sobre su conservación y promoción

> Difundir el patrimonio cultural universitario mediante la realización de muestras expositivas conjuntas y el intercambio de muestras individuales

> Sensibilizar al alumnado y a la sociedad en general sobre la necesidad de proteger y promocionar el patrimonio cultural universitario

¿En qué fase del proyecto nos encontramos ahora? Desde el Encuentro en Biar en mayo de 2003 hemos conseguido varios de los objetivos fijados:

www.patrimoniouniversitario.ua.es

La web recoge el patrimonio cultural de todas las universidades españolas (públicas y privadas), mediante una descripción del mismo, y muestra imágenes y detalles del organismo que gestiona el citado patrimonio. También se encuentran noticias sobre cualquier actividad en relación con el patrimonio cultural universitario y enlaces con otras webs que tratan el tema.

Actualmente disponemos de datos contrastados y puestos al día de 25 universidades, de ellas 24 son públicas.

Hoy por hoy, es todavía precipitado dar unos datos exactos respecto a todo el conjunto de universidades; se observa que éstas apuestan actualmente por las colecciones artísticas con lo que se ha producido un cambio frente a la tradición universitaria que apostaba por el patrimonio científico y natural. Si bien las colecciones artísticas (en las que se incluyen los inmuebles) proceden en gran parte de las universidades históricas, las universidades más modernas invierten en colecciones de arte contemporáneo. Este cambio se debe a que estos materiales ya no se utilizan tanto para la investigación, sino para la realización de actividades complementarias a la docencia y poseen un carácter cultural.

El principal problema que encontramos al aportar contenido a la web es la dificultad por obtener información. Es un trabajo arduo y difícil ya que no 
siempre obtenemos respuesta, hay que estar continuamente insistiendo para conseguir datos y esto produce que el proyecto se dilate en el tiempo. Además, el patrimonio es como un ser vivo, crece y esto obliga a estar permanentemente al día.

Nos ha sorprendido que muchas universidades no posean un inventario del patrimonio cultural con el peligro que conlleva por la posibilidad de deterioro, pérdida y robo de piezas. Con la difusión de la web pretendemos concienciar al gobierno de las universidades de dotar una infraestructura destinada al cuidado del patrimonio cultural, de aportar un presupuesto para el mismo y crear puestos de trabajo destinados a su gestión.

Otro de los vacios observado es el relativo a los derechos de autor y reproducción de imágenes. La normativa europea es muy rígida en este aspecto y existe un gran desconocimiento del mismo por parte de las universidades. Formamos parte del Espacio Europeo de Educación Superior y por ello debemos regular todo lo concerniente al patrimonio cultural como una parte más del propio ámbito universitario.

Reflexión y debate

Para ello hemos organizado un ciclo de conferencias sobre el patrimonio cultural intangible y los problemas de género durante los días 14 y 15 de abril de 2005, con la asistencia de distintos especialistas. Hemos querido comenzar con este curso por el desconocimiento que existe sobre el patrimonio intangible y para dar una definición correcta del mismo, así como incluir las cuestiones de género que a nivel de patrimonio están bastante olvidadas.

El próximo mes de octubre tenemos prevista la realización de un ciclo de conferencias sobre patrimonio cultural universitario a nivel internacional para poner en debate la situación del mismo tanto en España como fuera de nuestras fronteras.

Muestras expositivas

En el Encuentro de Extensión Universitaria en Biar de 2003, se lanzó la idea de la realización de un conjunto de muestras expositivas que con el título general "Imágenes de la Universidad" exhibiera el patrimonio cultural de nuestros centros universitarios. Se pensó comenzar por la imagen más cercana que corresponde a la arquitectura y urbanismo universitario. Se hizo un llamamiento a las universidades públicas españolas para que se integraran en el proyecto y conseguimos reunir a 22 universidades que están trabajando en la exposición "Imágenes de la universidad. Arquitectura universitaria: pasado y presente". El principal problema era la coordinación, por ello pedimos a la universidad que designara a una persona responsable. Contando con los coordinadores de cada universidad, se han realizado dos encuentros para concretar el proyecto, el primero de ellos tuvo lugar en Alicante en junio de 2004 y el segundo en Granada en noviembre del mismo año. En Granada se llegó a un acuerdo y comenzamos a trabajar mediante comisiones teniendo prevista la muestra para marzo de 2006. Es la primera vez que un número tan elevado de universidades se unen para llevar a cabo un proyecto expositivo común. Opinamos que alcanzar un acuerdo y trabajar conjuntamente es ya un gran éxito.

No llevamos mucho tiempo y sin embargo hemos conseguido poner el marcha los objetivos; la página web es una realidad y debido a su importancia ha sido incluida en la campaña de difusión de internet organizada por el Ministerio de Comercio Industria y Turismo "Todos.es en intrenet. Internet en nuestras vidas" (www.todos.es). Nuestro último reconocimiento ha sido formar parte del Tercer Informe del Programa Minerva (www.minervaeurope.org) consistente en la difusión de la cultura y el uso de las nuevas tecnologías en los 25 estados miembros de la Unión Europea. Este programa ha reconocido a Patrimonio Cultural Universitario como una de las iniciativas más interesantes e innovadoras en España.

Maria Marco Such

Coordinadora General

Universidad de Alicante

Abierto un espacio de crítica sobre la gestión de la cultura

La Gestión de la Cultura es la denominación del recién inaugurado sitio http://gestiondelacultura.blogspot.com, un lugar de reflexión y crítica sobre el porvenir de la cultura y los cambios producidos por el desarrollo del territorio y de la economía bajo situaciones turbulentas. El espacio está abierto para el debate sobre los consumos culturales, los conflictos, los derechos culturales y el desarrollo humano, así como para el intercambio de todo tipo de informaciones.

Más información:

Carlos F Caicoya

Profesor y consultor Independiente de proyectos culturales

Correo-e.: caicoya@eresmas.net 